\title{
Electricity Consumption and Economic Growth Nexus in the Republic of Benin
}

\author{
https://doi.org/10.21272/sec.3(2).63-69.2019
}

\section{Dossou Toyo Amegnonna Marcel}

PhD Candidate, School of Economics, Southwestern University of Finance and Economics, China

\begin{abstract}
This paper summarizes the arguments and counterarguments within the scientific discussion on the impact of electricity consumption in developing country especially in the Republic of Benin. The main purpose of the research is to examine the causal relationship between electricity consumption and economic growth in the Republic of Benin over the period 1971-2014. Systematization literary sources and approaches for solving the problem using Stationary test, the Johansen co-integration test, the vector autoregressive (VAR) model, and Granger causality test were used as econometric approach. The relevance of the decision of this scientific problem is that the electricity consumption may growth the Economy of the country. Methodological tools of the research methods were the results of 43 years of research on modeling. The object of research is to examine the impact of the electricity consumption in the economy growth in the Republic of Benin. The research empirically confirms and theoretically proves that there is bidirectional causality running from electricity consumption and economic growth. The results of the research can be useful for the government to invest more in energy to attract more foreign investors to boost the economy and to alleviate the poverty through reducing unemployment rate. In addition the causal relationship between energy consumption and economic growth in theRepublic of Benin represents a wildly studied topic in energy economic literature. Energy play a crucial role in the economics of the both developed and developing countries. The growth hypothesis suggest that energy consumption is an indispensable component in growth, directly and directly as complement to capital and labor as an input in the production process.
\end{abstract}

Keywords: economic growth, Granger causality, electricity consumption, VAR.

JEL Classification: Q43, C32.

Cite as: Marcel, D.T.A. (2019). Electricity Consumption and Economic Growth Nexus in the Republic of Benin. SocioEconomic Challenges, 3(2), 63-69. https://doi.org/10.21272/sec.3(2).63-69.2019.

(C) The Author, 2019. This article is published with open access at Sumy State University.

\section{Introduction}

Electricity is the major source of energy and plays a key role in economic growth in developed and developing countries. Its availability helps to meet residential and local needs, contributes to labor and capital productivity, promotes export of countries to create jobs, decline the poverty level and improves the socio-economic development. According to (Mulugeta, S. K., et al., 2010)it is considered as an important of growth, which indirectly and directly complement labor and capital as inputs in the production process.

Any country cannot attract foreign investors with weak electricity, and the aim of firm is to minimize the cost so the firm will avoid the country which energy is very costly. Without energy many sectors of an economy, as transport, industry, agribusiness, and services will cease exist. As mentioned by the international monetary fund in 2015, electricity is a crucial conductor of total factor productivity in an economy. More investment an energy infrastructure and good governance in an electricity sector will increase total factor productivity, available energy will alleviate poverty. This proves that investment in the energy sectors must be prioritized in all developing countries which facing electricity shortages especially in Benin where there were many electricity shortages. Benin has also faced tremendous amounts of electricity losses during distribution and transmission and was ranked $20^{\text {th }}$ in the world and $9^{\text {th }}$ in African in terms of electricity losses in 2015 according to EIA in 2018. According to US EIA report the losses of electricity in Benin was ranged between $9.35 \%$ and $25.14 \%$ 
of the total supply over the period 1980-2015; and it was proportionally around $19.358 \%$ of the total electricity supply. The causal nexus between energy consumption and economic growth has been the prime focus of the policymaker in Benin.

This study examines the relationship between electricity consumption and economic growth in Benin. As shown in figure 1, the electricity consumption (measured in $\mathrm{kWh}$ per capita )and economic growth (measured by real GDP per capita) in Benin have experienced an increased since 1971. From that period until 2014, electricity consumption increased from $10.75 \mathrm{kWh}$ to $100.22 \mathrm{kWh}$

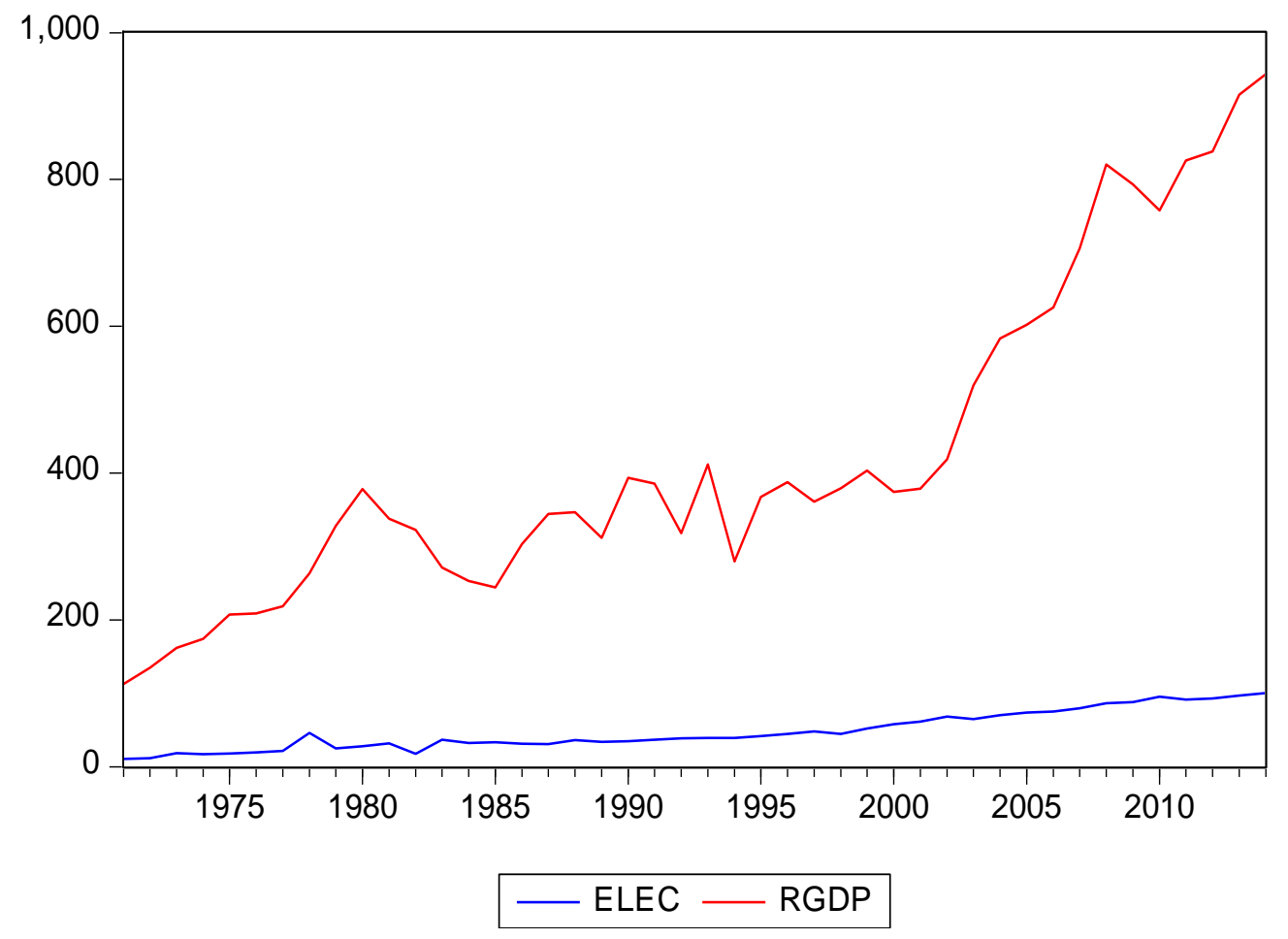

Figure 1. The gap between the Electricity consumption and Economic growth in the Republic of Benin

The aim of this paper is to examine empirically the existence and direction of causal nexus between electricity consumption and economic growth in Benin. The paper is organized in the following manner. Section 2 presents a literature review on empirical testing, and section 3 describes the data and econometric methodology and summarizes the obtained results the final section closes with conclusions

\section{Literature review}

The aim of this study is to examine the relationship between electricity consumption and economic growth the literature review is summarized in the table below.

Table 1a. Selected studies on the energy-led growth hypothesis

\begin{tabular}{|l|l|l|l|}
\hline \multicolumn{1}{|c|}{ Author(s) } & \multicolumn{1}{|c|}{ Countries } & \multicolumn{1}{c|}{ Methodology } \\
\hline $\begin{array}{l}\text { (Nela Vlahinic \& Pavle } \\
\text { Jakovac, 2014) }\end{array}$ & Croatia 1952-2011 co-integration & $\begin{array}{l}\text { Electricity consumption led } \\
\text { economic growth }\end{array}$ \\
\hline (Iyke, 2015) & Nigeria 1971-2011 & VECM & $\begin{array}{l}\text { Electricity consumption led } \\
\text { economic growth }\end{array}$ \\
\hline $\begin{array}{l}\text { (Xiao Shengfeng, et al., 2012) } \\
\text { (Dantama, 2012) }\end{array}$ & China 1953-2009 & $\begin{array}{l}\text { Electricity consumption led } \\
\text { economic growth }\end{array}$ \\
\hline $\begin{array}{l}\text { (Muhammad Shahbaz, et al., } \\
\text { 2011) }\end{array}$ & Pakistan 1972-2009 & Granger causality & $\begin{array}{l}\text { Electricity consumption led } \\
\text { economic growth }\end{array}$ \\
\hline
\end{tabular}


Table 1a (cont.). Selected studies on the energy-led growth hypothesis

\begin{tabular}{|l|l|l|l|}
\hline \multicolumn{1}{|c|}{ Author(s) } & \multicolumn{1}{|c|}{ Countries } & \multicolumn{1}{c|}{ Methodology } \\
\hline (Saleheen Khan, et al., 2018) & Kazakhstan 1991-2014 & ADRL and VECM & $\begin{array}{l}\text { Electricity consumption led } \\
\text { economic growth and trade } \\
\text { openness }\end{array}$ \\
\hline $\begin{array}{l}\text { (Yusuf Umar, et al., n.d.) } \\
\text { g.E.Akinlo, 2008) }\end{array}$ & Nigeria 1980-2010 & ADRL & $\begin{array}{l}\text { Energy Consumption led } \\
\text { Economic Growth }\end{array}$ \\
\hline $\begin{array}{l}\text { (Seung-HoonYoo \& So- } \\
\text { YoonKwak, 2010) }\end{array}$ & $\begin{array}{l}\text { South American Countries } \\
\text { 1975-2006 }\end{array}$ & Times series technique & $\begin{array}{l}\text { Energy Consumption led } \\
\text { Economic Growth }\end{array}$ \\
\hline $\begin{array}{l}\text { (NjindanIyke, 2015) } \\
\text { Economic Growth }\end{array}$ \\
\hline $\begin{array}{l}\text { (Chor FoonTang, et al., 2013) } \\
\text { Nigeria 1971-2011 led }\end{array}$ & Portugal 1974-2009 & VECM & $\begin{array}{l}\text { Energy Consumption led } \\
\text { Economic Growth }\end{array}$ \\
\hline $\begin{array}{l}\text { (Seung-Hoon Yoo \& Byoung- } \\
\text { Soh Hwang, 2016) }\end{array}$ & Nicaragua 1971-2010 & Granger causality & $\begin{array}{l}\text { Energy Consumption led } \\
\text { Economic Growth }\end{array}$ \\
\hline
\end{tabular}

Table 1b. Economic growth led energy hypothesis

\begin{tabular}{|l|l|l|l|}
\hline \multicolumn{1}{|c|}{ Author(s) } & \multicolumn{1}{|c|}{ Countries } & \multicolumn{1}{c|}{ Methodology } & \multicolumn{1}{c|}{ Conclusion(s) } \\
\hline (Ghosh, 2002) & India 1950-51 to 1996-97 & Granger causality & $\begin{array}{l}\text { Economic growth led } \\
\text { electricity consumption }\end{array}$ \\
\hline (Yoo, 2006) & $\begin{array}{l}\text { ASEAN (ThailanB,Singapore, } \\
\text { Indonesia, Malaysia) 1971- } \\
2002\end{array}$ & Granger causality & $\begin{array}{l}\text { Economic growth led } \\
\text { electricity consumption } \\
\text { (Thailand and Indonesia) }\end{array}$ \\
\hline $\begin{array}{l}\text { (Anita Kumari \& A.K. } \\
\text { Sharma, 2016) }\end{array}$ & India 1974-2014 & $\begin{array}{l}\text { Co-integration and Granger } \\
\text { causality }\end{array}$ & $\begin{array}{l}\text { Economic growth led } \\
\text { electricity consumption }\end{array}$ \\
\hline (Azlina, (2012) ) & Malaysia 1960-2009 & VECM & $\begin{array}{l}\text { Economic growth led } \\
\text { electricity consumption }\end{array}$ \\
\hline (Anon., 2016) & Lesotho 1972-2011 & ARDL & $\begin{array}{l}\text { Economic growth led } \\
\text { electricity consumption }\end{array}$ \\
\hline
\end{tabular}

Table 1c. feedback hypothesis

\begin{tabular}{|c|c|c|c|}
\hline Author(s) & Countries & Methodology & Conclusion(s) \\
\hline (Yoo, 2006 ) & $\begin{array}{l}\text { ASEAN (Thailand,Singapore, } \\
\text { Indonesia, Malaysia) 1971- } \\
2002\end{array}$ & Granger causality & $\begin{array}{l}\text { Bidirectional between } \\
\text { electricity consumption and } \\
\text { economic growth (Singapore } \\
\text { and Malaysia) }\end{array}$ \\
\hline (Aslan, 12 Aug 2013) & Turkey 1968-2008 & ARDL & $\begin{array}{l}\text { Bidirectional between } \\
\text { electricity consumption and } \\
\text { economic }\end{array}$ \\
\hline (Kasperowicz, 2014) & Poland 2000-2012 & Granger causality & $\begin{array}{l}\text { Bidirectional between } \\
\text { electricity consumption and } \\
\text { economic }\end{array}$ \\
\hline $\begin{array}{l}\text { (Lira Peter Sekantsi \& and } \\
\text { Nicholas Okot, 2016) }\end{array}$ & Uganda 1981-2013 & ARDL and Granger causality & $\begin{array}{l}\text { Bidirectional between } \\
\text { electricity consumption and } \\
\text { economic }\end{array}$ \\
\hline $\begin{array}{lr}\text { (Byoung-Soh } & \text { Hwang } \\
\text { Seung-Hoon Yoo, 2016) }\end{array}$ & Nicaragua 1971-2010 & Granger causality & $\begin{array}{l}\text { Bidirectional between } \\
\text { electricity consumption and } \\
\text { economic }\end{array}$ \\
\hline (Hasan, et al., August 2017) & 22 developed countries & $\begin{array}{l}\text { Dumistrecu Hurlin Pnael } \\
\text { causality analysis }\end{array}$ & $\begin{array}{l}\text { Bidirectional between } \\
\text { electricity consumption and } \\
\text { economic }\end{array}$ \\
\hline (M.Ouédraogo, 2010) & Burkina Faso 1968-2003 & A cointegration analysis & $\begin{array}{l}\text { Bidirectional between } \\
\text { electricity consumption and } \\
\text { economic }\end{array}$ \\
\hline
\end{tabular}


Table 1c (cont.). feedback hypothesis

\begin{tabular}{|l|l|l|l|}
\hline \multicolumn{1}{|c|}{ Author(s) } & \multicolumn{1}{|c|}{ Countries } & \multicolumn{1}{c|}{ Methodology } & \multicolumn{1}{c|}{ Conclusion(s) } \\
\hline (K.Kouakou, 2011) & Cote d'Ivoire 1971-2008 & $\begin{array}{l}\text { The cointegration and Granger } \\
\text { causality }\end{array}$ & $\begin{array}{l}\text { Bidirectional between } \\
\text { electricity consumption and } \\
\text { economic }\end{array}$ \\
\hline (UsamaAl-mulali, et al., 2013) & $\begin{array}{l}\text { High income, upper middle } \\
\text { income, lower middle income, } \\
\text { and high income countries }\end{array}$ & $\begin{array}{l}\text { The fully modified OLS } \\
\text { Bidirectional between } \\
\text { electricity consumption and } \\
\text { economic }\end{array}$ \\
\hline $\begin{array}{l}\text { (Soner Gokten \& Selim } \\
\text { Karatepe, 2016) }\end{array}$ & Turkey & $\begin{array}{l}\text { mis-specified statistical } \\
\text { models and biased outcomes }\end{array}$ & $\begin{array}{l}\text { Bidirectional between } \\
\text { electricity consumption and } \\
\text { economic }\end{array}$ \\
\hline
\end{tabular}

\section{Methodology}

\subsection{Sources of data}

The data mainly come from the database of the World Bank, particularly Africa Database CD-ROM 2018, and World Bank Indicators 2018. As for estimating, it will cover the period 1971 to 2014.

There are many amounts of studies on the determinants of economy growth particularly within the growth accounting framework. Forgoing studies have used as model TLG equations, where electricity consumption was assumed to a crucial determinant of economy growth. This study use two variables, the electricity consumption and GDP per capita and real, which have been deeply used in the empirical studies to find the relationship electricity consumption and economy growth. Hence the following equation presents the frame of the study. Each time series values were converted into their natural logarithms (L) before the analysis.

$\log R G D P_{t}=\alpha_{1}+\log E L E C_{t}+\varepsilon_{t}$

Where:

RGDP represents the real gross domestic per capita, ELEC represents electricity consumption per capita for each year.

$\varepsilon_{t}$ represents error term

Table 2. The original model

\begin{tabular}{|c|c|c|c|c|}
\hline Variable & Coefficient & Standard error & t- statistic & p-value \\
\hline LogELEC & 0.810863 & 0.050036 & 16.2055 & 0000 \\
\hline R2 $=0.862124$ & & & & \\
\hline F-statistic & 262.6206 & & & \\
\hline Mean dependent var & 5.925277 & & & \\
\hline
\end{tabular}

Source: authors' calculation using EVIEWS.

As shown the table 1 the electric consumption has positive impact to economic growth in Benin.

\subsection{Result of unit root and co-integration test}

(Nelson, C.R \& Plosser, C.I., 1982) Study showed that most of the macroeconomic time series data are not stationary so it is convenient to estimate the nexus through the regression method only if the series are stationary. To check whether or not the variables under consideration are stationary, one of the best for the test stationary this is Augmented Dicker Fuller (ADF) test is applied to natural logs of data series.

Conventionally to test for causal nexus between two variables, the standard Granger (1969) test has been are employed in the relevant literature. This test states, if values of a variable $Y$ significantly contribute to forecast the value of another variable $\mathrm{X}_{t+1}$ then $\mathrm{Y}$ is said Granger cause $\mathrm{X}$ and vice versa. The test is based on the following equations:

$\Delta L R G D P_{t}=\alpha_{1}+\sum_{i=1}^{k} \beta i 1 \Delta L R G D P_{t-1} \sum_{i=1}^{k} \gamma i 1 \Delta L E L E C_{t-1}+\theta_{1} E C T_{t-1}+\vartheta_{1 t}$ 
$\Delta L E L C_{t}=\alpha_{2}+\sum_{i=1}^{k} \beta i 2 \Delta L E L E C_{t-1} \sum_{i=1}^{k} \gamma i 2 \Delta R G D P_{t-1}++\theta_{2} E C T_{t-1}+\vartheta_{2 t}$

Where $\alpha$ is the constant term, $\Delta$ is the lag operator and $\beta, \gamma$ and are the coefficients of lagged independent variables. These coefficients capture the short-term dynamics effects of the independent variables on the dependent one. Besides, the Fischer test (F-test) of joint significance of these lagged terms constitutes the shortrun Granger causality. The parameter $\theta$ represents the speed of adjustment towards the long-run equilibrium. Similarly, the t-test associated with this parameter specifies the Granger causality of the long term.

Table 3. Summary of econometrical result

\begin{tabular}{|c|c|c|c|c|c|c|c|}
\hline \multicolumn{8}{|c|}{ Augmented Dicker-fuller unit root test. } \\
\hline \multirow{2}{*}{ Variables } & \multicolumn{2}{|c|}{ 1. No constant. No trend } & \multicolumn{2}{|c|}{ 2. Constant no trend } & \multicolumn{3}{|c|}{ 3. Constant trend } \\
\hline & t-statistic & p-value & t-statistic & p-value & & tistic & p-value \\
\hline \multicolumn{8}{|l|}{ level } \\
\hline LELEC & 2.178931 & 0.9920 & -1.850543 & 0.3518 & \multicolumn{2}{|c|}{-6.051547} & $0.0000^{*}$ \\
\hline LRGDP & 2.347043 & 0.99947 & -1.262058 & 0.6382 & \multicolumn{2}{|c|}{-2.987715} & 0.1473 \\
\hline \multicolumn{8}{|l|}{$\begin{array}{c}\text { First } \\
\text { difference }\end{array}$} \\
\hline$\triangle$ LELEC & -10.52696 & $0.0000 *$ & -5.280997 & $0.0000^{*}$ & \multicolumn{2}{|c|}{-8.24465} & $0.0000^{*}$ \\
\hline$\triangle \mathrm{RGDP}$ & -6.759745 & $0.0000^{*}$ & -7.583926 & $0.0000 *$ & \multicolumn{2}{|c|}{-7.511026} & $0.0000^{*}$ \\
\hline \multicolumn{8}{|c|}{ Johansen co-integration } \\
\hline $\begin{array}{c}\text { Null } \\
\text { hypothesis }\end{array}$ & Eigen value & t-statistic & $\mathrm{P}$ - value & \multicolumn{2}{|c|}{$\begin{array}{l}\text { Maximum Eigen } \\
\text { value statistic }\end{array}$} & \multicolumn{2}{|c|}{ p-value } \\
\hline None $(r=0)$ & 0.305733 & 18.7255 & 15.49471 & \multicolumn{2}{|c|}{15.32574} & \multicolumn{2}{|c|}{$0.00157^{*}$} \\
\hline At most (r=1) & 0.077824 & 3.402813 & 3.841466 & \multicolumn{2}{|c|}{3.402813} & \multicolumn{2}{|c|}{0.0651} \\
\hline \multicolumn{8}{|c|}{ VAR(-1) estimation } \\
\hline & \multicolumn{2}{|c|}{$\Delta \operatorname{LELEC}(-1)$} & \multicolumn{3}{|c|}{$\Delta \operatorname{LRGDP}(-1)$} & \multicolumn{2}{|c|}{$\mathrm{C}$} \\
\hline$\triangle$ LELEC & \multicolumn{2}{|c|}{0.324500} & \multicolumn{3}{|c|}{0.195998} & \multicolumn{2}{|c|}{-0.130285} \\
\hline t-statistic & \multicolumn{2}{|c|}{2.08118} & \multicolumn{3}{|c|}{0.089931} & \multicolumn{2}{|c|}{-0.18980} \\
\hline p-value & & & & & & & \\
\hline
\end{tabular}

Notes: *,* Significant at the $1 \%$ and $5 \%$ levels, respectively. $\mathrm{R}$ denotes the number of co-integrating equation. $\Delta$ represents the first difference.

Source: authors' calculation using EVIEWS 8.0.

The optimal lag length of variables is chosen by considering information on the VAR at levels. This is a necessary step before verifying the co-integration tests. Based on all information criteria, the optimal lag length of the VAR is one. Table 3 shows the results for the Johansen maximum likelihood co-integration test. Both the trace and maximal eigenvalue tests reveal the absence of a co-integrating function $\mathrm{R}=0$ and $\mathrm{R}=1$ at the 5\% level. It can be concluded from this test that there is no co-integrating equation for the series at the 5\% level.

Table 2 shows the result of Augmented Dickey Fuller unit root test the variable at their level and differenced values. The summary of the result indicates that the RGDP is stationary at level only in constant and trend. As for ELEC variable, the ADF test statistic revealed stationary at first difference

Table 4. Granger causality test

\begin{tabular}{|c|c|c|c|c|}
\hline Null hypothesis & Obs & Number of lags & F-statistic & p-value \\
\hline $\begin{array}{c}\text { LOGRGDP does not granger } \\
\text { cause LOGELEC }\end{array}$ & 43 & 1 & 8.57750 & $0.0056^{*}$ \\
\hline $\begin{array}{c}\text { LOGELEC does not granger } \\
\text { cause LOGRGDP }\end{array}$ & 43 & 1 & 9.5382 & $0.0036^{*}$ \\
\hline
\end{tabular}

Source: authors' calculation using EVIEWS 8.0. 
The results presented in Table 4 provide convincing evidence of a bidirectional causality running from electricity consumption to economic growth proxied by RGDP. The decision was taken from the probability and values. We therefore, reject the null hypothesis that energy consumption does not Granger cause real GDP and conclude that electricity consumption actually affects real GDP vice versa.

\section{Conclusion}

This paper aims to investigate the intersection between electricity consumption economic growths in the Republic of Benin. A times series analysis is driven to causal flow in the context of Granger causality from 19712014. The Stationary test, the Johansen co-integration test, the vector autoregressive (VAR) model, and Granger causality test were used as econometric approach. The empirical results established the existence of Granger causality running from electricity consumption to economic growth with feedback effect.

According to empirical result of this paper the electricity policies will have positive impact on economic growth in Benin. The study therefore recommends that the government should continue to provide more investment in this era to attract more foreign investors to boost the economic and alleviate the poverty also reduce the unemployment.

The policy implication of the findings suggests that energy conservation policies would not be implemented without undermining long-run economic growth Republic of Benin. It is therefore necessary for the government to have an integrated energy policy, which will guide future energy related sub-sectorial policy developments, in order to avoid policy conflicts which may otherwise arise.

\section{References}

1. Akinlo, A.E. (2008). Electricity consumption and economic growth in Nigeria: Evidence from cointegration and co-feature analysis. Journal of Policy Modeling, 31(5()), 681-693, https://doi.org/10.1016/j.jpolmod.2009.03.004

2. Anita Kumari \& A.K. Sharma (2016). Analyzing the causal relations between electric power consumption and economic growth in India. The Electricity Journal, 29, 28-35.

3. Anon (2016). Electricity consumption and economic growth in Lesotho. nergy Sources, Part B: Economics, Planning, and Policy, 11(10), 969-97326 http://dx.doi.org/10.1080/15567249.2013.876125.

4. Aslan, A. (2013). Causality Between Electricity Consumption and Economic Growth in Turkey:An ARDL Bounds Testing Approach. Energy Sources, Part B: Economics, Planning, and Policyю http://dx.doi.org/10.1080/15567241003681882.

5. Azlina, A. (2012). Energy Consumption and Economic Development in Malaysia: A Multivariate Cointegration Analysis. Procedia - Social and Behavioral Sciences, 65, 674-681.

6. Byoung-Soh Hwang \& Seung-Hoon Yoo (2016). Electricity consumption and economic growth in Nicaragua. nergy Sources, Part B: Economics, Planning, and Policy, 11(8), 746-752. http://dx.doi.org/10.1080/15567249.2013.781247.

7. Chor FoonTang, Muhammad Shahbaz \& Mohamed Arouri (2013). Re-investigating the electricity consumption and economic growth nexus in Portugal. Energy Policy, 62, 1515-1524. https://doi.org/10.1016/j.enpol.2013.07.073

8. Dantama, Y.U. (2012). The reltionship between energy consumption and economic growth in Nigeria. JORIND 10(3). www.transcampus.org./journals, www.ajol.info/journals/jorind.

9. Ghosh, A. (2002). Electricity consumption and economic growth in India. Energy Policy, 125-129.

10. Hasan, D., Serhat, Y. \& Zafer, A. (2017). Identifying Causality Relationship between Energy Consumption and Economic Growth in Developed Countries. International Business and Accounting Research Journal, 1(2), 71-81.

11. Iyke, B. N., 2015. Electricity consumption and economic growth in Nigeria: A revisit of the energygrowth debate. Energy Economics, 51, 166-176.

12. K.Kouakou, A. (2011). Economic growth and electricity consumption in Cote d'Ivoire: Evidence from time series analysis. Energy Policy, 38(6), 3638-3644. https://doi.org/10.1016/j.enpol.2011.03.069

13. Kasperowicz, R. (2014). Electricity Consumption and Economic Growth:Evidence from Poland. Journal of International Studies, 7(1), 46-57. DOI: 10.14254/2071-8330.2014/7-1/4. 
14. Lira Peter Sekantsi \& and Nicholas Okot (2016). Electricity consumption-economic growth nexus in Uganda. nergy Sources, Part B: Economics, Planning, and Policy, 11(12), 1144-1149 http://dx.doi.org/10.1080/15567249.2015.1010022.

15. M.Ouédraogo, I. (2010). Electricity consumption and economic growth in Burkina Faso: A cointegration analysis. Energy Economics, 32(3), 524-531. https://doi.org/10.1016/j.eneco.2009.08.011

16. Muhammad Shahbaz, V G R Chandran \& Pervaiz Azeem (2011). Natural Gas Consumption and Economic Growth:Cointegration, Causality and Forecast Error Variance Decomposition Tests for Pakistan. https://mpra.ub.uni-muenchen.de/35103/.

17. Mulugeta, S. K., Nondo, C, Schaeffer, P. V. \& Gebremedhin, T. G. (2010). Does level of income matter in the energy consumption and GDP nexus?: Evidence from sub-Saharan African countries. Research Paper No. 3, Research Institute, West Virginia University..

18. Nela Vlahinic \& Pavle Jakovac (2014). Revisiting the Energy Consumption-Growth Nexus for Croatia: New Evidence from a Multivariate Framework Analysis. Contemporary Economics, 8, 435-452. DOI: 10.5709/ce.1897-9254.155.

19. Nelson, C.R \& Plosser, C.I. (1982). Trends and Random Walks in Macroeconomics Time Series. Journal of Monetary Economics, 10, 139-162.

20. NjindanIyke, B. (2015). Electricity consumption and economic growth in Nigeria: A revisit of the energygrowth debate. Energy Economics, 51, 166-176. https://doi.org/10.1016/j.eneco.2015.05.024

21. Saleheen Khan, Farooq Ahmed Jam, Muhammad Shahbaz \& Md Al Mamun (2018). Electricity Consumption, Economic Growth and Trade Openness in Kazakhstan:Evidence from Cointegration and Causality. https://mpra.ub.uni-muenchen.de/87977/.

22. Seung-Hoon Yoo \& Byoung-Soh Hwang (2016). Electricity consumption and economic growth in Nicaragua. Energy Sources, Part B: Economics, Planning, and Policy, 11(8), 746-752. doi:10.1080/15567249.2013.781247.

23. Seung-HoonYoo \& So-YoonKwak (2010). Electricity consumption and economic growth in seven South American countries. Energy Policy, 38(1), pp. 181-188. https://doi.org/10.1016/j.enpol.2009.09.003

24. Soner Gokten \& Selim Karatepe (2016). Electricity consumption and economic growth: A causality analysis for Turkey in the frame of import-based energy consumption and current account deficit. Energy Sources, Part B: Economics, Planning, and Policy, 11(4), https://doi.org/10.1080/15567249.2012.666332.

25. Usama Al-mulali, Hassan Gholipour Fereidouni, Janice YmLee \& Che Normee Binti CheSab (2013). Examining the bi-directional long run relationship between renewable energy consumption and GDP growth. Renewable and Sustainable Energy Reviews, 22, 209-222, https://doi.org/10.1016/j.rser.2013.02.005.

26. Xiao Shengfeng, Xu ming Sheng, Zhu Tianxing \& Zhang Xuelli (2012). The Relationship between Electricity Consumption and Economic Growth in China. Physics Procedia, 24, 56-62.

27. Yoo, S.-H. (2006). The causal relationship between electricity consumption and economic growth in the ASEAN countries. Energy Policy, p. 34 3573-3582.

28. Yusuf Umar, D., Yahya Zakari, A. \& Nasiru, I., n.d. (2012). Energy consumption-Economic growth nexus in Nigeria: an empiricaly assessment based on ADRL bound test Approch. European Scientific Journal, $8(12), 142-175$. 